\title{
THE APPLICATION OF GREEN ECONOMY TO ENHANCE PERFORMANCE OF CREATIVE INDUSTRIES THROUGH THE IMPLEMENTATION OF BLUE OCEAN STRATEGY: A CASE STUDY ON THE CREATIVE INDUSTRIES
}

\author{
Asj'ari F., Subandowo M., Bagus I M.D. \\ Researchers, Indonesia \\ *E-mail: fachrudy@unipasby.ac.id
}

\begin{abstract}
This research intended to asses the green economy to enhance the performance which must be performed of the creative industries in connection with performance of the employee. This research was conducted at creative industries which covered 108 employees as respondent. This research by utilizing Structural Equation Modeling (SEM), the technique was processed with AMOS program 6.0 to analyze some hypothesis. The intercorrelations models between these variables in this study revealed that three hypothesis have significant correlation. The result of this research was empirical data of the development of the theoretical of human resources and practice management.
\end{abstract}

\section{KEY WORDS}

Green economy, Blue Ocean, strategy, performance.

This research proves there is no company that has always excelled, when there is no industry that has always excelled. As found in the course of a winding up, as well as companies that do things smarter and things that are not intelligent. To improve the quality of success, it is necessary that we make what colleagues specializing in ancient times that has produced a positive difference and understand how repeating the actions that systematically. This is what is called a smart strategy, measures and found that the strategic measures that are important is creating an ocean-Ocean Blue (2007:10).

According to Kim and Mauborgne (2007:10), blue ocean strategy States (blue ocean strategic), challenging the company to get out of the bloody red ocean competition by way of creating a space market that its competitors do not yet exist, so the word any competition no longer relevant. Red ocean strategic versus a blue ocean strategic can be seen in the following table:

Table 1 - Ocean Strategies

\begin{tabular}{|l|l|}
\hline \multicolumn{1}{|c|}{ Red Ocean Strategic Blue Ocean Strategic } & \multicolumn{1}{c|}{ Blue Ocean Strategic } \\
\hline Competing in an existing market & Space creates a market space that no rivals \\
\hline Winning the competition & Making the competition irrelevant \\
\hline Exploit existing demand & Creates demand and capture new \\
\hline Choose between cost (value-cost trade-offs) & Breaking down Exchange-value cost \\
\hline $\begin{array}{l}\text { Integrating the entire system of corporate activities with the } \\
\text { strategic choice between low cost or differentiation Combines }\end{array}$ & $\begin{array}{l}\text { The entire system of corporate activities in } \\
\text { pursuit of differentiation and low cost }\end{array}$ \\
\hline
\end{tabular}

Indonesia's economic growth become the background of this article to see the extent to which balance economic growth with this consciousness of the maintenance of a sustainable environment. In Indonesia, the mindset towards Green Growth necessary for a harmonious balance between economic growth and a sustainable environment, to shift from the mindset to Grow First, Clean up Later. This article has research purposes namely to State perceptions of Green Industry in Indonesia, especially relating to the present conditions, challenges and a new mindset. The second objective, is to analyze and enforce up the present conditions in Indonesia, accompanied by the current Challenges associated with economic growth in Indonesia, where a further need for a mindset towards Green Growth. All purpose mentioned supported the Foundation of the theory of energynomics and 
methodology of DPSIR (Driving Forces, Pressure, State, Impact and Response), and thus created an understanding and concrete actions for the development of the Green Industry. Economic growth is expected to lead to a new mindset towards Green Growth in real action from all company categories Low, Medium and High impact.

\section{LITERATURE REVIEW}

Green Industry. Green economic or green Industry can not be separated from a number of factors, especially when associated with situations and conditions in Indonesia, in an era of rapid economic growth, along with a similar growth in Asia Pacific, as has been discussed in table 1, table 2, Figure 1 and Figure 2. Later, Chung \& Quah (2010), states the existence of a relationship between the following factors in the Green Industry, namely economic growth and the environmental performance and economic growth and environmental sustainability.

In the economic growth and environmental performance, economic growth is associated with the ability of the environment, i.e. the efficiency of environmental administration organizers in reducing pollution and protecting the environment. In Indonesia, the Government's participation as organizer of the environmental administration was instrumental in the ability of this environment, which is certainly need for support from all parties. While, in economic growth and environmental sustainability, economic growth associated with the sustainability of the environment, i.e. the efficiency of ecology, where Community production and consumption activities.

More specifically can be put forward that in Indonesian society, the process of the industrialization society along with the growth of industrial production activity through several companies. So, to answer the problem in Indonesia is expected to within the scope of the larger again, Green Industry, can align simultaneously between economic growth with Environmental Performance and Environmental Sustainability. When associated with the process of industrialization which is characterized by the growth of the industry of some companies in Indonesia, it should be noted that there is a pollution level. In this Green Industry may refer to a pattern called the Environmental Kuznets Curve (EKC). Chung \& Quah (2010), describes the EKC with some of the following statement: at the level of per capita income is low enough, the level of pollution in the beginning will increase at a time when income increases. However, once it reaches a certain threshold, the level of pollution will decrease with increasing income. Furthermore, EKC in theory, explained that at the time of economic growth and industrialization, the level and intensity of pollution emissions will increase, due to the high activity of production of goods and services.

Green Economy. The concept of green economy is currently being hotly discussed. The green economy is the economy of optimizing the three groups, namely the value of the value of social, environmental, and financial. The definition of a green economy that is sustainable in environmental, social, and fair in its roots. Green Economics refers to economic activities which have considered the social environment and in order to obtain a better benefit from investment in natural, human, and economic capital. Indonesia is a country rich in natural resources. Indonesia is a developing country that is constantly working to improve the economy of the country. When the economy and the environment is not increased correspondingly, the trade off between economic development and will affect the well-being of the community.

Economic development essentially on natural resources and the environment. One of the functions of the environment that is as life support by providing natural resources as raw materials to be processed into a product. There are environmental degradation will affect the economy. For example, when the supply of human food needs decrease environmental degradation will occur due to imbalance of the market that would affect consumer and producer surplus. These imbalances will affect the welfare of society (human welfare).

In 2017 must be better than the previous year. Economic development is not yet take into account the environmental aspects must be shifted on the green economy. Promotion on green marketing should continue to introduce to consumers that the eco-friendly products 
that have added value and benefit more. It is these obstacles in implementing the green economy. The benefits of a green economy relative to the long term so that the community is difficult watching him and feel the benefits in no time.

The Government has already made efforts in building a green economy in the system of rice intensification of whom (SRI) and organic farming. Resolutions regarding green economy must continue to be supported and developed optimally. Rules on environmental pollution should be taken into account. Coaching about green economy should be exposed so that companies can environmentally. The community was given the direction and understanding of the importance of safeguarding the environment.

Knowledge about renewable energy, environmentally friendly technology, and systems based on the environment should be supported and continue to be developed in order to be better implemented in 2017 and for years to come. Let us keep our environment as well as supporting and realizing the program of green economy.

In simple way, the sense of a green economy formulated as activities of an economy that does not harm or damage the environment. Meanwhile, the United Nations Environment Programme (UNEP) to associate the notion of green economy with economic significance that is able to enhance the well-being and social justice, by giving the sense that: Greening the economy refers to the process of reconfiguring business and infrastructure to deliver better returns on natural, human and economic capital investments, while at the same time reducing greenhouse gas emissions, extracting and using less natural recources, creating less waste and reducing social disparities.

The concept of green economy (green economy) become the paradigm of sustainable development which is essential in tackling the impact of climate change is happening. Green economy more or less be the answer from Brown's economy, namely the economic activities that produce lots of carbon. Brown economy is economic activity that uses energy in inefficient (wasteful) but not enough socially inclusive, that does not involve a lot of people in the process of taking its decision. In relation to the management and utilization of materials mines and minerals such as coal, Brown was dominant economic activities.

Green economy according to Cato (2009), has the following characteristics:

- A green economy is an economy based locally;

- In the green economy, people will relate to each other first and then traded. The market is seen as a place for socializing and friendship fun where news and political views are exchanged as well as goods and money;

- The green economy is very likely involves the distribution of assets by using the improved inheritance and capital gains tax;

- In the green economy, taxes likely used also strategically to influence power and business conduct. Neoliberal domination of decision-making resulted in the shifting of the corporation tax to the income of the population;

- The green economy will be guided by the values of sustainability rather than by value for money;

- The green economy will leave the addiction on economic growth and lead to a steady-state economy;

- The green economy will become a friendly economy oak where relationships and community becomes a substitute for the consumption and technology;

- Green economy gives it a wider role for the informal economy and the system of community-based cooperatives and mutual support;

- In the green economy, the health system will focus on the development of good health and the provision of primary care, local-based rather than high-tech medicine and pharmaceutical companies;

- The green economy will replace fossil fuels and intensive farming systems with organic agriculture and various systems such as agriculture with the support of the community, in which human beings are connected more closely with the source pangannya. 
There are at least 4 dimensions which are used to measure the success of a country promoting green economic model in support of the activities of its construction. These four aspects are: the commitment of national leaders, an environmentally friendly domestic policies, investment-friendly environment, and economic activities such as tourismdimensional environment. The process of internalization of the concept of green economy (green economy) in the setting of policies and the management and utilization of natural resources, must be based on principles of natural resource management contained in Ordinance No. IX/MPR MPR/2001 of Agrarian reform and the management of natural resources, namely:

- Maintain and defend the integrity of Unitary State of Republic of Indonesia;

- Respecting and upholding human rights;

- Respect for the rule of law with computing diversity in unification of law;

- Welfare, primarily through an increase in the quality of human resources Indonesia;

- Develop democracy, legal compliance, transparency and optimization of popular participation;

- Realizing justice including gender equality in mastery, possession, usage, utilization and maintenance of agrarian resources/natural resources;

- Maintain sustainability can give optimal benefits, both for the present generation or future generations by remaining attentive to the capacity and resources support neighborhood;

- Carry out social functions, sustainability and ecological functions in accordance with the social conditions of the local culture;

- Enhancing coordination and alignment of development sectors and between regions in the implementation of agrarian reform and the management of natural resources;

- Recognize, respect and protect the rights of customary law society and cultural diversity of the nation over the agrarian resources/natural resources;

- Maintains a balance of rights and obligations of the State, the Government (Central, provincial, district/regional towns and villages or level) the community and the individual;

- Implementing a decentralized form of Division of authority at the national level, the region of the province, kabupaten/kota and the village or level, relating to the allocation and management of agrarian resources/natural resources.

The twelve principles of natural resource management at the top, if it was concluded on 3 main principles are conical, namely:

- The principle of democratic equality in dimension between the Government with the people, community empowerment and the development of good governance in Mastering and exploiting natural resources;

- The principle of fairness, in the philosophical dimension of both intergenerasi as well as justice justice between the generations in an effort to access the agrarian resources;

- The principle of sustainability, in the dimension of sustainability function and benefits the Sepik and successful action.

Green Ocean Strategic. To formulate strategies, the company should make a choice based on the analysis of internal, external, environmental and industry. In the stage of formulation of the green ocean strategic assumption is that industry is growing as environmental change, and the company has the option to stay in the same industry or be part of a growing industry.

In the formulation of the green ocean strategy company assumption is not creating new industries. The industry is evolving due to changes in the environment, and that smart companies recognize the evolution of the industry and looking for new opportunities because of these changes. Despite the name, the green ocean strategy is not about greening or environmental. Rather, it is a discipline strategy which concentrates on how to maximize the internal remains, and human resources. Copy or benchmarking against competitors, the focus was to be more realistic in relation to what the business can actually do or provide. 
Studies show that the company's main frustration is that they set goals not being met. However, this should also be seen from the opposite point of view: how it targets determined? Whether they are logical, reasonable and fair? Sometimes, management may not relate to the true state of the business process, people skills or even customer feedback. Sometimes, the decision was made based on the wrong assumptions.

Green ocean strategy begins with the assessment process of the internal competency what these companies, how they rate and what the impact is. Then it focuses on the existing markets that are served as well as a potential market. From here, it validates if there is a match between versus what the company can really give the current market. Nine strategies are then available to the Organization to grow in a sea of green, depending on the results of the assessment. We will discuss this strategy in the next issue.

Knowledge-based economy for companies to create an atmosphere of uncontested market by creating a product or service by combining components from two different industries. In the blue ocean strategy, creating uncontested market space by innovation service is not a good suggestion. The company recognized opportunities in the marine industry that is expanding and moving into the market with a strategy of differentiation. The marine industry has not made an uncontested market space. Companies compete for revenues in the marine industry by implementing a strategy of differentiation.

I believe that the best way to learn about the company's strategy is to observe and experience businesses that provide their product or service. Decision making process emphasizes the fact that the marine industry creating uncontested market space, marine industry operates in a competitive environment. The current financial situation proves that the company does not create a new industry or create a blue ocean and the competition alive. The concept of the blue ocean is not a practical choice for the formulation stage of the strategy. This brings us back to a strategy of growth and sustainable development, which means that the green ocean strategy is the best strategy for success in the market.

Performance. Herriegel et al. (1989:143), stating the individual's performance as a result of the multiplication or a function of motivation and ability. Performance formula is as follows performance $(P)=$ function (Ability and motivation); or performance $=f(x$ ability motivation). Gibson (1996:95) States that the employee's performance level is a measure that can be used to specify the comparison of the results of the execution of the task, the responsibility given by the Organization in a certain period and the relative can be used to measure the accomplishments of the work or the performance of the organization. According to Simamora (2004:339-340) performance indicators include: Absenteeism, Tardiness, length of time, quantity and quality of work produced, protective Action, cooperation, constructive Ideas, training and attitude profitable.

\section{METHODS OF RESEARCH}

In this research analysis using SEM (structural equation modelling). According to Ferdidand (2002:6), structural equation Models, structural equation modelling (SEM) is a set of techniques that allow a statistikal testing a series of relationships that are relatively "complicated" simultaneously. The complicated relationships that can be established between one or more of the dependent variable with one or more independent variables. Sampling techniques using proportional random sampling with a sample number of 108 people. Ferdinand (2002:33), SEM can do modeling steps are as follows: 1). The development of a theoretical model, 2). diagram of the path of Development, 3). diagram of the path of Conversion into the equation, 4). The selection of the input matrix and estimation models, 5). Assessing the problem identification, 6). The evaluation Model, 7). Interpretation and modification of the model.

\section{RESULTS AND DISCUSSION}

In this section, expressed about the outcome of the analysis based on print out SEM. In the analysis of SEM, there are two main components of the analysis model of measurement 
(measurement model) and the structural model (structural models). Model measurement (measurement model) concerns the analysis whether the indicators really are valid and reliability measure invalid constructs (unobserved variable), while structural model (structural models) concerning the analysis of the influence of a invalid constructs against other invalid constructs.

Table 1 - The assumptions of SEM

\begin{tabular}{|ccc|c|ccc|}
\hline & HUBUNGAN & & ESTIMASI & P & ALPHA & LABEL \\
\hline Y1 & $<---$ & X1 & 0.511 & 0.002 & 0.05 & Signifikan \\
Y2 & $<---$ & Y1 & 0.349 & 0.013 & 0.05 & Signifikan \\
Y2 & $<---$ & X1 & 0.288 & 0.027 & 0.05 & Signifikan \\
GE4 & $<---$ & X1 & 0.565 & 0.000 & 0.05 & Signifikan \\
GE3 & $<---$ & X1 & 0.851 & 0.000 & 0.05 & Signifikan \\
GE2 & $<---$ & X1 & 0.392 & 0.000 & 0.05 & Signifikan \\
GE1 & $<---$ & X1 & 0.585 & 0.000 & 0.05 & Signifikan \\
BOS1 & $<---$ & Y1 & 0.826 & 0.000 & 0.05 & Signifikan \\
BOS2 & $<---$ & Y1 & 0.683 & 0.000 & 0.05 & Signifikan \\
BOS3 & $<---$ & Y1 & 0.615 & 0.000 & 0.05 & Signifikan \\
BOS4 & $<---$ & Y1 & 0.548 & 0.000 & 0.05 & Signifikan \\
BOS5 & $<---$ & Y1 & 0.482 & 0.000 & 0.05 & Signifikan \\
K1 & $<---$ & Y2 & 0.557 & 0.000 & 0.05 & Signifikan \\
K2 & $<---$ & Y2 & 0.374 & 0.000 & 0.05 & Signifikan \\
K3 & $<---$ & Y2 & 0.628 & 0.000 & 0.05 & Signifikan \\
K4 & $<---$ & Y2 & 0.827 & 0.000 & 0.05 & Signifikan \\
K5 & $<---$ & Y2 & 0.843 & 0.000 & 0.05 & Signifikan \\
K6 & $<---$ & Y2 & 0.534 & 0.000 & 0.05 & Signifikan \\
K7 & $<---$ & Y2 & 1.01 & 0.000 & 0.05 & Signifikan \\
K8 & $<---$ & Y2 & 0.494 & 0.000 & 0.05 & Signifikan \\
K9 & $<---$ & Y2 & 0.372 & 0.000 & 0.05 & Signifikan \\
\hline
\end{tabular}

Both models are related, and this means that the model must be valid and measurement reliability, can proceed with structural equation analysis. Because if the measurement model is invalid then the structural model is not good because the indicators that are used are not capable of measuring the invalid constructs which should be as measured.

Analysis of measurement model. In this section will be described about three main things model measurements are: first, about the value of loading factor or regression weight (component estimate) or lamda (ferdinand, 2002:79). Second, about the level of their significance in each invalid constructs. Third, about the construct of reliability. However this measurement model, the most important is the level of signifiansinya (must be less than $5 \%$ or 0.05 ) and the value of the construct of reliability $(\rho n ́)>0.70$. Study variables are said to be valid if it has a value of unidimensional Goodness of Fit Index (GFI) $>0.90$.

Loading Factor. Loading factor value shows the weighting of each indicator as a measure of each variable. Indicator with large loading factor indicates that an indicator measuring variables such as the strongest (dominant).

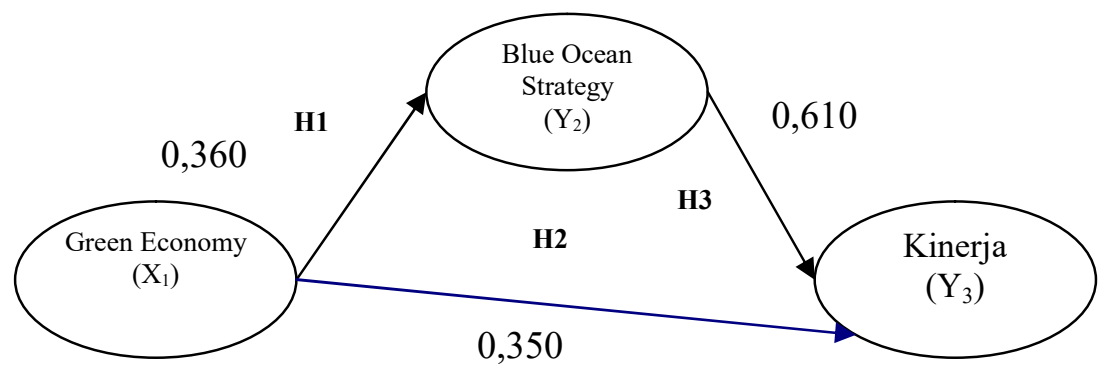

Figure 1 - Research Model

Each Path Coefficient of Relationship between Invalid Constructs. For the coefficients of the line, as the standard in the analysis of SEM, used component's. The standardized 
coefficients, are used because this coefficient refers to the net contribution from a direct relationship between the variables.

The top line of the influence coefficient of green economy (X1) to the blue ocean strategy $(\mathrm{Y} 1)$ of 0.360 . This means if the green economy $(\mathrm{X} 1)$ rises then the blue ocean strategy $(Y 1)$ will increase. Conversely, if the green economy $(X 1)$ get down then the blue ocean strategy (Y1) will decrease. Practically, this means that any improvements of the green economy of creative industries would increase the blue ocean strategy of creative industries in ,.

The top line of the influence coefficient of green economy (X1) against performance (Y2) of 0.350 . This means if the green economy (X1) increases then the performance (Y2) will increase. Conversely, if the green economy (X1) get down then the performance (Y2) will decrease. Practically, this means that any improvements of the green economy will improve the performance of the creative industries.

The top line of influence coefficient of blue ocean strategy (Y1) against performance (Y2) of 0.610. This means if the blue ocean strategy (Y1) increases then the performance (Y2) will increase. Conversely, if the blue ocean strategy (Y1) get down then the performance (Y2) will decrease. Practically, this means any repairs of blue ocean strategy will improve the performance of the creative industries.

The Results of Hypothesis Testing. Hypothesis testing is done with test $t$ ( $t$ test) on each line partially direct influence. A complete analysis of the results is contained in the results of the analysis of SEM.

Hypothesis 1: the Green economy (X1) effect significantly to the blue ocean strategy (Y1). The SEM analysis results variable green economy (X1) to the blue ocean strategy (Y1) 0.360 path coefficient were obtained and the p-value 0.002 . Then there is enough empirical evidence to accept the hypothesis that the "green economy" (X1) effect significantly to blue ocean strategy (Y1). Given the marked path coefficient is positive $(0.360)$, meaning the relationship both this variable is positive, it means the better the green economy, then the higher the blue ocean strategy employees.

Hypothesis 2: Green economy (X 1) effect significantly to performance (Y2). The SEM analysis results variable Green economy (X1) to the performance (Y2) 0.350 path coefficient were obtained and the $p$-value 0.013 . Then there is enough empirical evidence to accept the hypothesis that the "Green economy" (X1) effect significantly to performance (Y2). Given the marked path coefficient is positive $(0.350)$, meaning the relationship both this variable is positive, it means the better the Green economy, then the higher the performance of employees.

Hypothesis 3: Blue ocean strategy (Y1) significant effect on performance (Y2). The SEM analysis results variable Blue ocean strategy (Y1) to the performance (Y2) 0.610 path coefficient were obtained and the p-value of 0.027 . Then there is enough empirical evidence to accept the hypothesis that "Blue ocean strategy (Y1) significant effect on performance (Y2)". Given the marked path coefficient is positive (0.610), meaning the relationship both these variables are positive, meaning that the higher the Blue ocean strategy, then the higher the performance of employees.

\section{CONCLUSION}

Blue ocean strategy gives a dominant influence on performance of creative industry.

The necessity of maintaining the Blue Ocean strategy impacting positively on the performance of, and working to reduce the negative impact of the culture. It is realized, it is no easy job as it pertains to mental attitude. Similarly facing cross cultural, we should be able to distinguish and filter cross cultural influences.

The performance of creative industry still needs refinement and development in order to face globalization.

The application of the norms of the green economy that is universal in Indonesia should be adjusted with the lofty values and culture of the nation of Indonesia. 
Pearls of wisdom on value of Javanese culture coloring and contribute valuable against the performance of the creative industry.

\section{REFERENCES}

1. Akhmad Fauzi, Ekonomi Hijau untuk Bumi, Artikel pada Surat Kabar Harian KOMPAS, Jakarta, 7 Juli 2012.

2. Cato, M.S., Green Economics: An Introduction to Theory, Policy and Practice, earthscan, London, 2009, dalam Sudarsono Soedomo, Ekonomi Hijau: Pendekatan Sosial, Kultural dan Teknologi, makalah pada Diskusi "Konsep Ekonomi Hijau/Pembangunan Ekonomi yang Berkelanjutan untuk Indonesia, Jakarta 14 Juli 2010.

3. Chay Asdak, Kajian Lingkungan Hidup Strategis: Jalan Menuju Pembangunan Berkelanjutan, Gadjah Mada University Press, Yogyakarta, 2012.

4. Daud Silalahi, Pembangunan Berkelanjutan dalam Rangka Pengelolaan (termasuk Perlindungan) Sumber Daya Alam berbasis Pembangunan Sosial Ekonomi, Makalah pada Seminar Pembangunan Hukum Nasional VIII, Bali 14-18 Juli 2003.

5. Fungsi dan Peran Asuransi dalam Perlindungan dan Penegakan Hukum Lingkungan, Makalah pada Seminar Nasional "Peran Asuransi Lingkungan dalam Pemberian Ganti Kerugian bagi Masyarakat dan Pemulihan Lingkungan, Fakultas Hukum Unpad, Bandung 13 September 2012.

Ditjen Pengelolaan Lahan dan Air (PLA) Kementerian Pertanian, Strategi dan Kebijakan Pengelolaan Lahan, Jakarta, 2005.

6. Emil Salim, Ratusan Bangsa Merusak Satu Bumi, Penerbit KOMPAS, Jakarta, 2010.

7. Hariadi Kartodihaedjo dan Hira Jhamtani (penyunting), Politik Lingkungan dan kekuasaan di Indonesia, Equinox Publishing Indonesia-Ford Foundation, Jakarta, 2006.

8. Hasim Purba, Reformasi Agraria dan Tanah untuk Rakyat: Sengketa Petani vs Perkebunan, artikel pada Jurnal Law Review, Volume X, No. 2 November 2010.

9. Ida Nurlinda, Prinsip-prinsip Pembaruan Agraria: Perspektif Hukum, Raja Grafindo Persada, Jakarta, 2009.

10. Koesnadi Hardjasoemantri, Hukum Tata Lingkungan, Gadjah Mada Press, Yogyakarta, 2006.

11. Laksmi Dhewanthi, Kebijakan Instrumen Ekonomi Lingkungan Hidup: Asuransi bagi Perlindungan dan Pengelolaan Lingkungan Hidup, Makalah pada Seminar Nasional "Peran Asuransi Lingkungan dalam Pemberian Ganti Kerugian bagi Masyarakat dan Pemulihan Lingkungan, Fakultas Hukum Unpad, Bandung, 13 September 2012.

12. Makmun, Green Economy: Konsep, Implementasi dan Peranan Kementerian Keuangan, Artikel dalam Jurnal “Ekonomi dan Pembangunan", LIPI, volume XIX (2) 2011.

13. Maria Sumardjono, Transnasional Justice atas Hak Sumber Daya Alam, tulisan dalam buku Himpunan tulisan Komnas HAM: Keadilan dalam Masa Transisi, Komnas HAMJakarta, 2001.

14. Otto Soemarwoto, Pembangunan Berkelanjutan antar Konsep dan Realitas, Ceramah umum ulang tahun Otto Soemarwoto ke-80 di Universitas Padjadjaran, Bandung, 20 Februari 2006.

15. Sonny Mumbunan, Ekonomi Hijau dan Pemerintahan Bersih, www.perspektifbaru.com, diunduh 1 Juni 2012.

16. Velix Wanggai, Menuju Ekonomi Hijau, Artikel pada Jurnal Nasional, Jakarta, 28 Juni 2012. 